\title{
Impact of Plasmatic Progesterone on the Day of Frozen Embryo Transfer in Hormone-induced Cycles
}

\section{Impacto da progesterona plasmática no dia da transferência de embriões congelados em ciclos induzidos por hormônios}

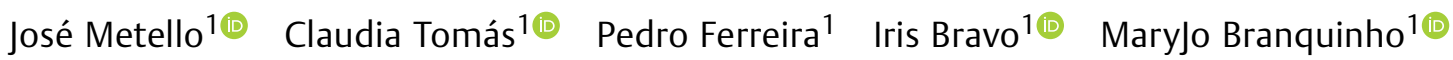

Samuel Santos-Ribeiro ${ }^{20}$

${ }^{1}$ Hospital Garcia de Orta, Almada, Portugal

2 Instituto Valenciano de Infertilidad, Lisboa, Portugal

Address for correspondence José Luís Metello, Hospital Garcia de Orta, Av. Torrado da Silva, 2805-267, Almada, Portugal

Rev Bras Ginecol Obstet 2021;43(8):608-615.

(e-mail: jmetello@gmail.com).

\begin{abstract}
Objective To establish a relationship between serum progesterone values on the day of frozen blastocyst transfer in hormone-replaced cycles with the probability of pregnancy, miscarriage or delivery.

Methods This was an ambispective observational study including all frozen-thawed embryo transfer cycles performed at our department following in vitro fecundation from May 2018 to June 2019. The outcomes evaluated were $\beta$ human chorionic gonadotropin ( $\beta$-hCG)-positive pregnancy and delivery. Groups were compared according to the level of serum progesterone on the day of embryo transfer: the $1^{\text {st }}$ quartile of progesterone was compared against the other quartiles and then the $2^{\text {nd }}$ and $3^{\text {rd }}$ quartiles against the $4^{\text {th }}$ quartile.

Results A total of 140 transfers were included in the analysis: 87 with $\beta$-HCG $>10$ IU/L (62\%), of which 50 (36\%) delivered and 37 had a miscarriage (42\%). Women with lower progesterone levels $(<10.7 \mathrm{ng} / \mathrm{mL}$ ) had a trend toward higher $\beta$-HCG-positive (72 versus $59 \% ; p>0.05$ ), lower delivery ( 26 versus $39 \% ; p>0.05$ ) and higher miscarriage

Keywords

- progesterone

- blastocyst

- frozen embryo transfer

- artificial cycle

- miscarriage

- delivery rates (64 versus $33 \% ; p<0.01)$. Comparing the middle quartiles $(P 25-50)$ with those above percentiles 75 , the rate of pregnancy was similar (60 versus $57 \% ; p>0.05$ ), although there was a trend toward a higher number of deliveries ( 43 versus $31 \%$; $p>0.05$ ) and a lower number of miscarriages ( 28 versus $45 \% ; p>0.05$ ). These differences were not statistically significant.

Conclusion There were no differences in pregnancy and delivery rates related with the progesterone level when measured in the transfer day. The miscarriage rate was higher in the $1^{\text {st }}$ quartile group.
\end{abstract}

received

June 30, 2020

accepted

July 23, 2021
DOI https://doi.org/

10.1055/s-0041-1735229. ISSN 0100-7203.
(C) 2021. Federação Brasileira de Ginecologia e Obstetrícia. All rights reserved.

This is an open access article published by Thieme under the terms of the Creative Commons Attribution License, permitting unrestricted use, distribution, and reproduction so long as the original work is properly cited. (https://creativecommons.org/licenses/by/4.0/)

Thieme Revinter Publicações Ltda., Rua do Matoso 170, Rio de Janeiro, RJ, CEP 20270-135, Brazil 


\section{Resumo}
Palavras-chave
- progesterona
- blastocisto
- transferência de embrião congelado
- ciclo artificial
- aborto
- parto

Objetivo Avaliar se existe alguma relação entre os valores plasmáticos de progesterona no dia da transferência de um blastocisto desvitrificado em ciclos hormonalmente substituídos e a taxa de gravidez, aborto ou nascido vivo.

Métodos Estudo observacional, ambispectivo, incluindo todos os ciclos de transferência de blastocistos congelados no nosso departamento, entre maio de 2018 e junho de 2019. Avaliou-se a taxa de gravidez e de nascidos vivos após 24 semanas de gestação. Os grupos foram comparados de acordo com os valores de progesterona plasmáticos dosados no dia da transferência do blastocisto: comparou-se o $1^{\circ}$ quartil com os outros e depois os $2^{\circ}$ e $3^{\circ}$ quartis com o $4^{\circ}$.

Resultados Avaliaram-se 140 transferências: 87 com $\beta$ gonadotrofina coriônica humana ( $\beta$-HCG) $>10 \mathrm{IU} / \mathrm{L}$ (62\%), 50 das quais terminaram em nascido vivo (36\% do total), enquanto 37 tiveram um aborto (42\% das gravidezes). Verificou-se uma tendência para menor número de recém-nascidos nas transferências com níveis de progesterona no $1^{\circ}$ quartil $(<10.7 \mathrm{ng} / \mathrm{mL})(26$ versus $39 \%$; $p>0.05)$ e um maior número de abortos ( 64 versus $33 \% ; p<0.01$ ). Comparando o $2^{\circ}$ e $3^{\circ}$ quartis com o $4^{\circ}$, verificouse que nos casos em que a progesterona estava acima do percentil 75 , apesar de uma taxa de gravidez semelhante ( 60 versus $57 \% ; p>0.05$ ), houve uma tendência para uma maior taxa de nascidos vivos (43 versus $31 \% ; p>0.05$ ) e menor número de abortos ( 28 versus $45 \%$; $p>0.05$ ) abaixo do percentil 75 . Estas diferenças não foram estatisticamente significativas.

Conclusão Não se verificaram diferenças estatisticamente significativas para taxa de gravidez e de nascido vivo. A taxa de aborto foi maior no primeiro quartil.

\section{Introduction}

Over the past decade, with the development of the vitrification technique and the consequent increase in embryo survival rate, frozen embryo transfers (FETs) have increased considerably. ${ }^{1}$ The latest data published by the European Society of Human Reproduction and Embryology (ESHRE) shows that $>248,000$ frozen embryo transfers or endometrial preparation cycles for oocyte donation embryos have been performed across Europe. ${ }^{2}$ Some of the reasons behind this increase have been the use of elective embryo cryopreservation to reduce both the risk of hyperstimulation syndrome and the multiple pregnancy rate by following a single embryo transfer (SET) policy and, possibly, the intent of physicians to prevent a potential negative impact of supraphysiological hormonal levels during ovarian stimulation. ${ }^{3}$ Moreover, another contributing factor is the increasing popularity of preimplantation genetic testing. ${ }^{4}$

Endometrial preparation in FETs can be achieved in natural, modified, or artificial hormone substituted cycles, with no significant differences being reported to date in terms of clinical pregnancy and livebirth rates between the three preparation methods. ${ }^{5,6}$ That said, the artificial hormone-substituted cycle has been most frequently used due to its ease in terms of scheduling and greater control of exogenous progesterone (P4) exposure, which is essential for achieving embryo-endometrial synchrony. ${ }^{7,8}$

Endometrial receptivity appears to be related with the time and dose of P4 exposure after adequate estrogen exposure, since $\mathrm{P} 4$ is essential for embryo implantation and pregnancy outcome. ${ }^{9}$ Exogenous P4 may be adminis- tered orally, vaginally, subcutaneously (SC) or intramuscularly (IM). Vaginal and IM administration were the most studied, with neither showing superiority over the other in terms of pregnancy outcomes. ${ }^{10}$ However, the vaginal method is often preferred. ${ }^{11,12}$ More recently, the oral route has also been evaluated as an alternative, showing to be noninferior, at least when used in fresh embryo transfers. ${ }^{12,13}$

Recent evidence suggests an important role of measuring serum progesterone values to predict the outcome of pregnancy. According to Gaggiotti-Marre et al., ${ }^{14}$ a serum P4 value $<10.64 \mathrm{ng} / \mathrm{mL}$ on the day prior to FET of euploid embryos is associated with a higher miscarriage rate and with a lower live newborn rate. Another prospective observational study conducted on recipients of oocyte donor embryos found that a P4 value $<9.2 \mathrm{ng} / \mathrm{mL}$ on the day of FET is associated with a decreased rate of ongoing pregnancy. ${ }^{15}$ On the other hand, although less consistently, high P4 levels ( $>20 \mathrm{ng} / \mathrm{mL}$ ) have also been associated with worse outcomes. ${ }^{16}$

The aim of the present study was to evaluate if the serum P4 values on the day of frozen blastocyst transfer in hormonereplaced cycles are related with pregnancy, miscarriage, or delivery.

\section{Methods}

This was an observational, ambispective study of FETs performed at the Centro de Infertilidade e Reprodução Medicamente Assistida (CIRMA) of the Hospital Garcia de Orta, Almada, Portugal, from May 2018 to June 2019, with the prospective collection of data commencing in September 2018. 
All the cycles of women aged between 18 and 39 years old who had 1 or 2 frozen blastocysts transferred with an expansion degree $\geq 2$ and with a grade 1 or 2 internal cell mass and trophectoderm (Istanbul Consensus, 2011) in a hormone-substituted cycle were included. ${ }^{17}$

Patients with an endometrium $<6 \mathrm{~mm}$ prior to $\mathrm{P} 4$ administration, with endocavitary pathology or an uncorrected Mullerian anomaly, or those who obtained a P4 value not compatible with a luteal phase $(<2 \mathrm{ng} / \mathrm{mL})$ were excluded from the analysis.

On the $2^{\text {nd }}$ day of a spontaneous or postpill menstrual cycle, the patient started estradiol (Zumenon ${ }^{\circledR}$, Bayer Portugal, SA, Portugal) at a dose of $2 \mathrm{mg}$ vaginally each 12 hours. Ultrasound control was performed 12 to 20 days later. If the endometrial lining was trilaminar and with a thickness $>7 \mathrm{~mm}$, the patients started vaginal administration of P4 (Progeff®, Laboratórios Effik, Portugal) at a dose of $400 \mathrm{mg}$ each 12 hours starting on the following morning.

A serum P4 assay was performed on the day of ultrasound for confirmation of anovulation, and another one on the morning of the transfer after the $11^{\text {th }}$ vaginal P4 administration.

A maximum of 2 embryos were warmed according to the following protocol: the Cryotop straw (Kitazato, Japan) was removed from liquid nitrogen and immediately submerged in $300 \mu$ l of thawing solution (Kitazato, Japan) previously heated to $37^{\circ} \mathrm{C}$. After 1 minute, the embryos were placed in a $60 \mu \mathrm{l}$ drop of diluent solution (Kitazato, Japan) for 3 minutes at room temperature. Finally, they were placed in a $60 \mu \mathrm{l}$ drop of washing solution (Kitazato, Japan) for 5 minutes at room temperature, and then were washed for 1 minute in another drop of $60 \mu \mathrm{l}$ of washing solution at room temperature. They were then placed into $30 \mu$ drops of Sequential Blast medium (ORIGIO, Denmark) covered with Liquid Paraffin (ORIGIO, Denmark), where they remained for at least 2 hours prior to transfer.

Embryo transfers are routinely performed under ultrasound guidance in our center using either a Cook or Wallace embryo catheter introduced until it passes the middle of the endometrial cavity, where the embryos are deposited. All transfers were performed by physicians with at least 100 previously performed transfers. One or two blastocysts were transferred. The $\beta$-HCG test was performed 9 to 12 days after the transfer and, in those who conceived, estradiol and P4 were maintained until the $12^{\text {th }}$ week of pregnancy.

Progesterone and $\beta$-HCG hormone assays were performed using electrochemiluminescence (ECLIA) and the Modular EVO E170 Roche Diagnostics (Roche Holding AG, Basel, Switzerland) equipment. The $\beta$-HCG assay method was based on sandwich-type immunological reaction, and the P4 assay on competitive immunological reaction.

A $\beta$-HCG-positive pregnancy was considered in all cycles with a serum $\beta$-HCG value $>10 \mathrm{IU} / \mathrm{L}$. Delivery was considered in all pregnancies delivering a liveborn after 24 weeks. The miscarriage rate was calculated as the difference between delivery rate and a $\beta$-HCG value $>10 \mathrm{IU} / \mathrm{L}$.

We estimated a delivery rate of $50 \%$ in the highest quartile of patients against $25 \%$ in lowest one. In this case, considering an $\alpha$-error of $5 \%$ with an $80 \%$ power, we estimated that 232 cases were needed for analysis.

The following variables were subject to statistical analysis: female age on the day of the oocyte retrieval, body mass index (BMI) of women and men, smoking habits of women and men, ethnicity of women and men, anti-Mullerian hormone $(\mathrm{AMH})$ value, antral follicle count (AFC), total dose of gonadotropins used in the IVF/ICSI cycle, number of oocytes and embryos obtained, blastocyst development day (D5 or D6), number of transferred embryos, FET rank, endometrium thickness prior to FET, serum P4 value on the day of FET, and transfer difficulty rating (easy or difficult).

A percentile distribution was made according to the serum P4 levels measured on the day of FET.

A p-value $<0.05$ was considered statistically significant. Continuous variables were compared with the MannWhitney test, and discrete variables with the chi-squared test. IBM SPSS Statistics for Windows, version 22.0 (IBM Corp., Armonk, NY, USA) software was used.

The present study was approved by the Ethics Committee of the Hospital Garcia de Orta. Informed consent was obtained from patients followed prospectively $(n=102)$ on the day of the FET scheduling consultation.

\section{Results}

The investigation team decided to prematurely terminate the study for ethical reasons after the publication of several studies in 2019 suggesting worse results in women with lower P4 values. A review of the 140 cases already included in the study at the time was performed, with 38 being retrospective and 102 prospective. There were 87 cases with $\beta$-HCG $>10 \mathrm{IU} / \mathrm{L}$ (62\%), 50 cases with delivery (36\%), and 37 cases of miscarriage (42\%). The P4 concentration on the day of the embryo transfer varied between 2.6 and $26.6 \mathrm{ng} / \mathrm{mL}$ (-Fig. 1). Women were grouped in 4 quartiles according to these values. The $1^{\text {st }}$ quartile (P4 $<10.7 \mathrm{ng} / \mathrm{mL}$ ) was compared with the rest. As shown in - Table 1, women with lower P4 levels had a higher number of pregnancies (71 versus 59\%) but a lower rate of deliveries (26 versus 39\%), although these differences were not statistically significant. Moreover, the miscarriage rate was almost double among women with lower P4 levels (64 versus 33\%; $p<0.01$ ).

All the other variables evaluated were compared between groups (-Tables 2 and $\mathbf{3}$ ). Although no statistically significant differences were found, in the group with lower P4 values, there were more day 6 blastocyst transfers (31 versus $18 \%$ ) and more transfers ranked as being the $1^{\text {st }}$ (77 versus $69 \%)$. The only statistically significant difference was male BMI (28.3 versus 24.9).

A comparison was also made between percentiles 25-75 (P4 10.7 to $15.7 \mathrm{ng} / \mathrm{mL}$ ) and $>75$ (P4 $>15.7 \mathrm{ng} / \mathrm{mL}$ ). The results are shown in -Table 4 . The rate of pregnancy was similar (60 versus 57\%), although there was a trend toward a higher number of deliveries (43 versus $31 \%$ ) and a lower number of miscarriages (28 versus $45 \%$ ) in the P4 25-75 


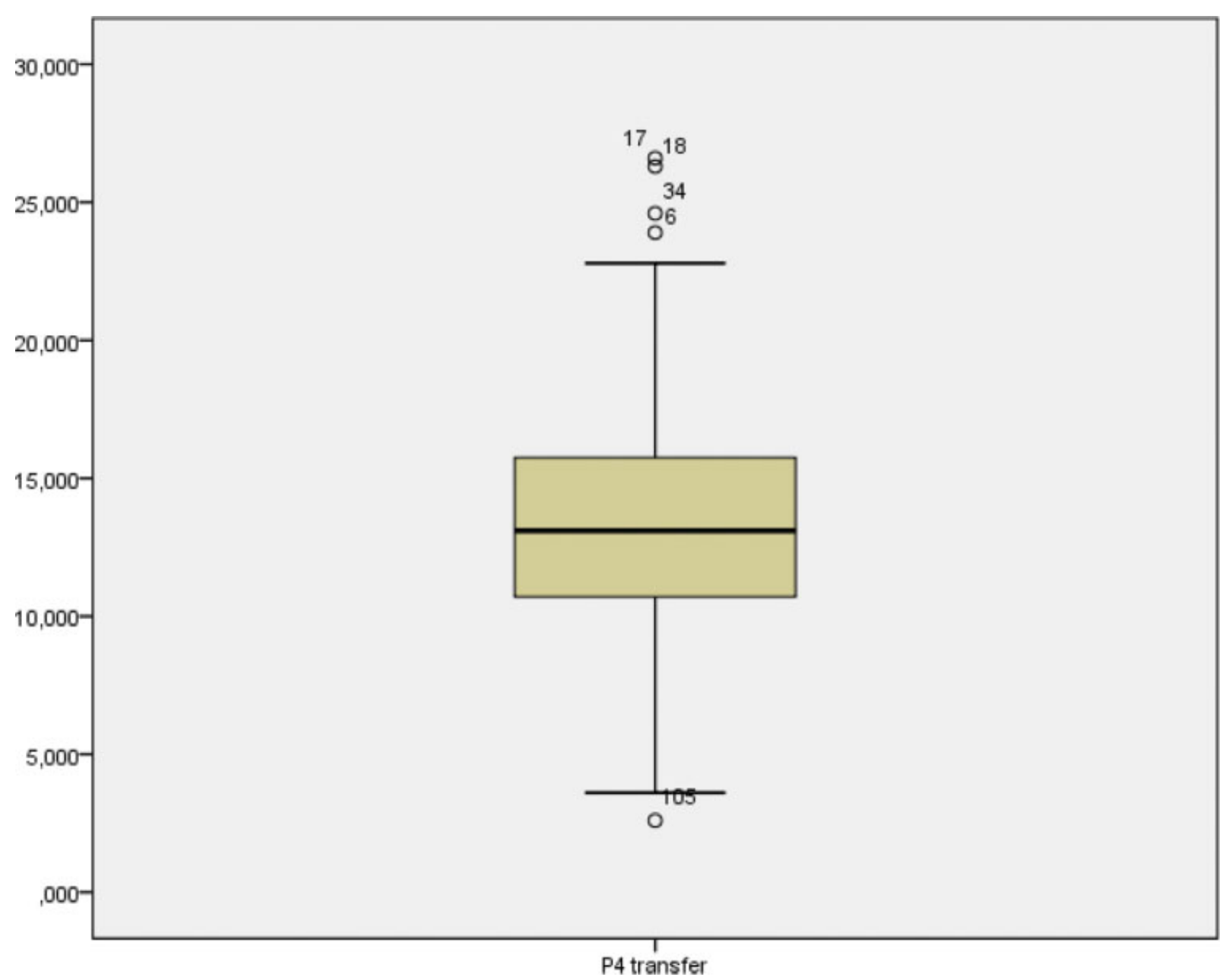

Fig. 1 Progesterone steam and leaf distribution of progesterone $(\mathrm{ng} / \mathrm{mL})$.

Table 1 Comparison between p25, p25-100

\begin{tabular}{llll}
\hline & $\begin{array}{l}\text { Progesterone } \\
<10.7 \mathrm{ng} / \mathrm{mL} \\
(\boldsymbol{n}=35)\end{array}$ & $\begin{array}{l}\text { Progesterone }> \\
\begin{array}{l}10.7 \mathrm{ng} / \mathrm{mL} \\
(\boldsymbol{n}=\mathbf{1 0 5})\end{array}\end{array}$ & $p$-value \\
\hline$\beta$-HCG + & $71 \%$ & $59 \%$ & 0.191 \\
Deliveries & $26 \%$ & $39 \%$ & 0.154 \\
Miscarriage & $64 \%$ & $33 \%$ & 0.009 \\
\hline
\end{tabular}

percentile group. However, this difference was not statistically significant.

\section{Progesterone Variation among Women}

Given the trend toward worse outcomes in the extremes, a correlation between age, weight, height and BMI was performed in relation to progesterone values. There is not any statistically significant correlation between P4 values and weight or BMI.

\section{Discussion}

The present study was designed to evaluate whether P4 values measured on the transfer day of a blastocyst in a FET cycle were related with pregnancy, delivery, or miscarriage rates. Unfortunately, the study was terminated prematurely due to ethical concerns related to the loss of study equipoise. The evaluation of the results showed a trend toward a worse outcome amongst women with lower P4 levels and in those with higher values (delivery rate for P4 < $10.7 \mathrm{ng} / \mathrm{mL}$ : $26 \%$ versus $43 \%$ for P4 between 10.7 and $15.7 \mathrm{ng} / \mathrm{mL}$ versus $31.4 \%$ when $\mathrm{P} 4$ is over $15.7 \mathrm{ng} / \mathrm{mL}$ ). Currently, there are several studies published regarding the existence of a minimal cutoff of serum P4 value to be achieved in hormone-substituted FET cycles, under which there appears to be a significant decrease in pregnancy rates (- Table $\mathbf{5}$ ).

Generally, higher P4 values are often associated with better outcomes in FETs. However, some studies suggest a maximum serum $\mathrm{P} 4$ value above which a decrease in pregnancy rates and an increase in miscarriage rates may become evident. ${ }^{16,19}$

Except for the studies by Labarta et al., ${ }^{15,23}$ all studies are retrospective and, therefore, have the biases inherent to this type of study. Moreover, they are highly variable regarding the type and dose of P4 administered on the day of dosing as well as the knowledge of embryo ploidy and their cleaved or blastocyst status, thus reflecting the heterogeneity of clinical practice. 
612 Impact of Plasmatic Progesterone in Hormone-induced Cycles Metello et al.

Table 2 Comparison between p25, p25-100

\begin{tabular}{|c|c|c|c|}
\hline & $\begin{array}{l}\text { Progesterone } \\
<10.7 \mathrm{ng} / \mathrm{mL} \\
(n=35)\end{array}$ & $\begin{array}{l}\text { Progesterone } \\
>10.7 \mathrm{ng} / \mathrm{mL} \\
(n=105)\end{array}$ & p-value \\
\hline \multicolumn{4}{|l|}{ Female smoking habits $n(\%)$} \\
\hline Before & $7(20 \%)$ & $16(15 \%)$ & 0.793 \\
\hline Never & 20 (57\%) & 62 (59\%) & \\
\hline Present & $8(23 \%)$ & $27(26 \%)$ & \\
\hline \multicolumn{4}{|l|}{ Male smoking habits $n$ (\%) } \\
\hline Before & $7(20 \%)$ & $16(15 \%)$ & 0.368 \\
\hline Never & $18(51 \%)$ & $45(43 \%)$ & \\
\hline Present & $10(29 \%)$ & $44(42 \%)$ & \\
\hline \multicolumn{4}{|l|}{ Female ethnicity $n(\%)$} \\
\hline Caucasian & $29(83 \%)$ & $93(89 \%)$ & 0.382 \\
\hline Noncaucasian & $6(17 \%)$ & $12(11 \%)$ & \\
\hline \multicolumn{4}{|l|}{ Male ethnicity $n(\%)$} \\
\hline Caucasian & $31(89 \%)$ & $92(88 \%)$ & 0.881 \\
\hline Noncaucasian & $4(11 \%)$ & $13(12 \%)$ & \\
\hline \multicolumn{4}{|l|}{ Infertility cause $n(\%)$} \\
\hline Idiopatic & $11(31 \%)$ & $23(22 \%)$ & 0.517 \\
\hline Endometriosis & $6(17 \%)$ & $18(17 \%)$ & \\
\hline Ovulatory & $1(3 \%)$ & $13(12 \%)$ & \\
\hline Tubar & $1(3 \%)$ & $12(11 \%)$ & \\
\hline Multiple female & $1(3 \%)$ & $2(2 \%)$ & \\
\hline Male factor & $11(31 \%)$ & $28(27 \%)$ & \\
\hline Male and female factors & $4(11 \%)$ & $7(7 \%)$ & \\
\hline Other & $0(0 \%)$ & $2(2 \%)$ & \\
\hline \multicolumn{4}{|l|}{ Fecundation method $n$ (\%) } \\
\hline IVF & $22(63 \%)$ & $65(62 \%)$ & 0.965 \\
\hline ICSI & $12(34 \%)$ & $36(34 \%)$ & \\
\hline Mixed & $1(3 \%)$ & $4(4 \%)$ & \\
\hline \multicolumn{4}{|l|}{ Embryo development $n$ (\%) } \\
\hline D5 blastocyst & $24(69 \%)$ & $86(82 \%)$ & 0.096 \\
\hline D6 blastocyst & $11(31 \%)$ & $19(18 \%)$ & \\
\hline \multicolumn{4}{|c|}{ Number of transferred embryos $n(\%)$} \\
\hline 1 embryo & $28(80 \%)$ & $82(78 \%)$ & 0.812 \\
\hline 2 embryos & $7(20 \%)$ & $23(22 \%)$ & \\
\hline \multicolumn{4}{|l|}{ FET rank $n(\%)$} \\
\hline First & $27(77 \%)$ & $72(69 \%)$ & 0.505 \\
\hline Second & $7(20 \%)$ & $25(24 \%)$ & \\
\hline Third & $1(3 \%)$ & $8(8 \%)$ & \\
\hline
\end{tabular}

Abbreviations: FET, Frozen embryo transfer; IVF, In vitro Fertilization; ICSI, Intracytoplasmic injection.

In natural cycles, the adequate value of produced $\mathrm{P} 4$ by the corpus luteum seems to be $\sim 10 \mathrm{ng} / \mathrm{mL},{ }^{24,25}$ although their values may fluctuate from cycle to cycle. ${ }^{26}$ According to the endometrial implantation window theory, ${ }^{7}$ there is an optimal period for embryonic implantation, which is between the $19^{\text {th }}$ and $20^{\text {th }}$ day and may last up to 4 or 5 days; in other words, 5 to 9 days after ovulation, midway through the luteal and secretory phase. ${ }^{27}$ However, its duration may vary inter- and intracyclically in each menstrual cycle. ${ }^{7}$ Therefore, based on this implantation window and considering the minimum and
Table 3 Comparison between p25, p25-100

\begin{tabular}{|c|c|c|c|}
\hline & $\begin{array}{l}\text { Progesterone } \\
<10.7 \mathrm{ng} / \mathrm{mL} \\
(n=35)\end{array}$ & $\begin{array}{l}\text { Progesterone }> \\
10.7 \mathrm{ng} / \mathrm{mL} \\
(n=105)\end{array}$ & p-value \\
\hline Female age (mean/SD) & $34.3(3.53)$ & $34.1(3.79)$ & 0.813 \\
\hline $\begin{array}{l}\text { Duration of infertility (months) } \\
\text { (mean/SD) }\end{array}$ & $62.2(27.8)$ & $59.3(26.1)$ & 0.346 \\
\hline $\begin{array}{l}\text { Endometrial thickness (mm) } \\
\text { (mean/SD) }\end{array}$ & 9.65 (1.99) & $9,47(1.86)$ & 0.791 \\
\hline Female weight $(\mathrm{kg})($ mean/SD) & $67.3(14.1)$ & $66.2(15.0)$ & 0.640 \\
\hline Female BMI $\left(\mathrm{kg} / \mathrm{m}^{2}\right)($ mean/SD) & $25.3(5.1)$ & $24,96(5.2)$ & 0.657 \\
\hline Male age (mean/SD) & $36.3(5.5)$ & $35.1(4.8)$ & 0.372 \\
\hline Male BMI $\left(\mathrm{kg} / \mathrm{m}^{2}\right)($ mean $/ \mathrm{SD})$ & $28.3(5.4)$ & $24.9(3.6)$ & 0.000 \\
\hline AMH (ng/mL) (mean/SD) & $3.54(3.7)$ & $3.84(3.3)$ & 0.292 \\
\hline AFC (mean/SD) & $18.2(12.5)$ & $19.8(12.4)$ & 0.398 \\
\hline $\begin{array}{l}\text { Total gonadotropin dose (UI) } \\
\text { (mean/SD) }\end{array}$ & $2863(805)$ & $2738(770)$ & 0.367 \\
\hline $\begin{array}{l}\text { Number of oocytes retrieved } \\
\text { (mean/SD) }\end{array}$ & $14.0(9.0)$ & $15.1(7.4)$ & 0.305 \\
\hline $\begin{array}{l}\text { Number of MIl oocytes } \\
\text { (mean/SD) }\end{array}$ & $13.4(8.8)$ & $13.9(7.1)$ & 0.399 \\
\hline $\begin{array}{l}\text { Number of obtained embryos } \\
\text { (mean/SD) }\end{array}$ & $9.7(6.5)$ & $9.2(6.1)$ & 0.921 \\
\hline $\begin{array}{l}\text { Number of cryopreserved } \\
\text { embryos (mean/SD) }\end{array}$ & $3.5(2.5)$ & $3.4(2.3)$ & 0.868 \\
\hline
\end{tabular}

Abbreviations: AFC, Antral follicle count; AMH, Anti-mullerian hormone; BMI, Body mass index; MII, metaphase II; SD, standard deviation.

Table 4 Comparison between p 25-75 and over p75

\begin{tabular}{llll}
\hline & $\begin{array}{l}\text { Progesterone } \\
10.7-15.7 \mathrm{ng} / \mathrm{mL} \\
(\boldsymbol{n}=\mathbf{7 0 )}\end{array}$ & $\begin{array}{l}\text { Progesterone } \\
>15.7 \mathrm{ng} / \mathrm{mL} \\
(\boldsymbol{n}=35)\end{array}$ & p-value \\
\hline$\beta$-HCG + & $60 \%$ & $57 \%$ & 0.779 \\
Deliveries & $43 \%$ & $31 \%$ & 0.258 \\
Miscarriage & $28 \%$ & $45 \%$ & 0.180 \\
\hline
\end{tabular}

maximum cutoff of serum P4, transferring an embryo outside these values may correspond to an asynchrony between endometrial and embryonic development, reducing implantation rates. ${ }^{16,18,21}$ Low P4 may delay the implantation window, while higher P4 may advance the implantation window, thus shifting the transfer from the optimal period for embryo implantation. For the first case, one may speculate that extra P4 supplementation may be considered; on the other hand, in the second case, a reduction in the dose could be an option.

In the case of low P4 values, an effective "rescue" strategy is yet to be established. In the studies by Cédrin-Durnerin et al. ${ }^{22}$ with vaginal P4 and by Brady et al. ${ }^{18}$ with IM P4, on the day of P4 dosing $\left(6^{\text {th }}\right.$ and $4^{\text {th }}$ day of therapy, both corresponding to the day of FET), if the serum P4 values were $<10$ and $<20 \mathrm{ng} / \mathrm{mL}$, respectively, the supplementation administered to the patient would be doubled in the first study ( $400 \mathrm{mg} 3 \mathrm{id}$ ) and, in the second study, the IM P4 dose would be increased by between 50 and $100 \% .22$ In both cases, a new dosing was performed 2 to 4 days after the P4 dose increase. Despite 


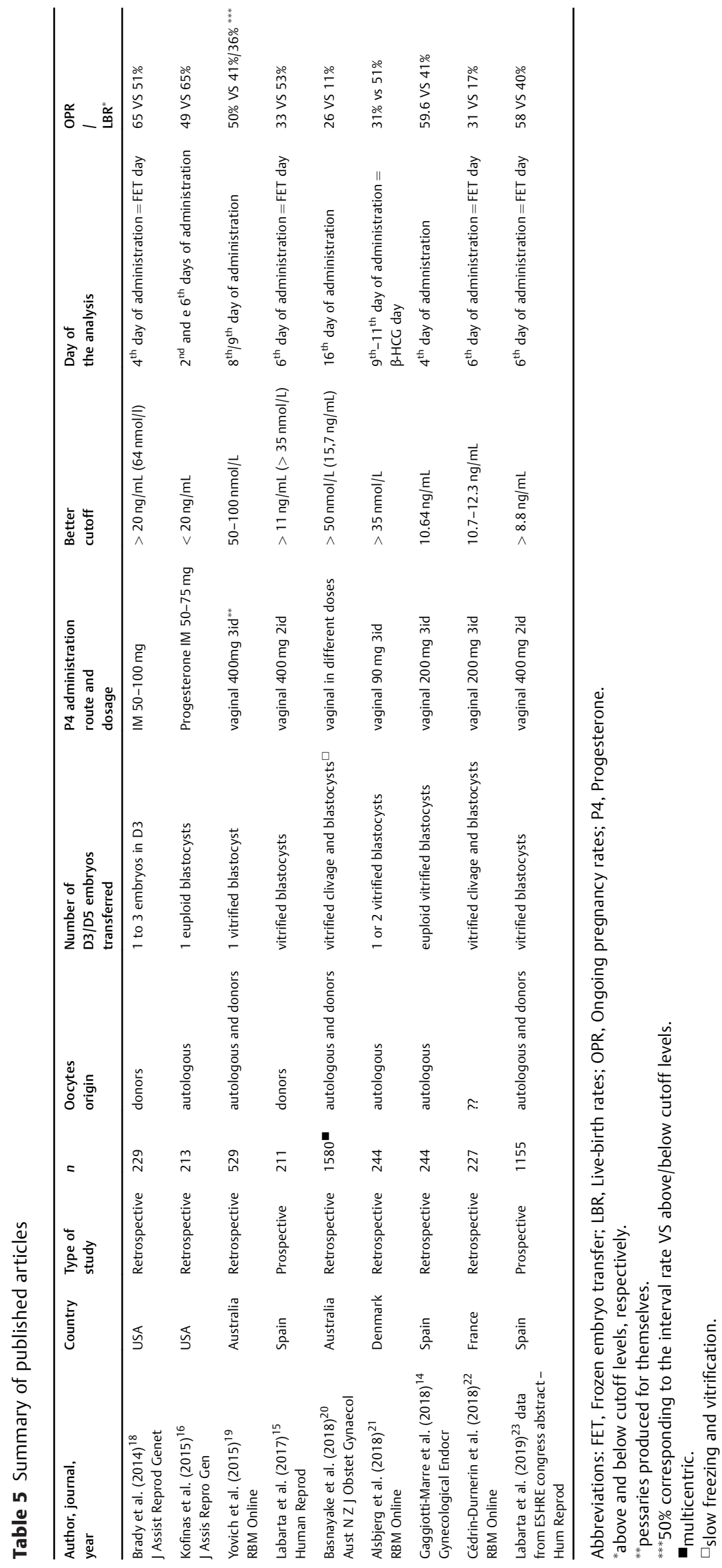


supplementation, these groups maintained worse rates of ongoing pregnancy and livebirth rates, which may demonstrate that the supplementation adjustments were ineffective, possibly because the correction might have been made too late. In this case, the ideal may be to dose $\mathrm{P} 4$ on the $2^{\text {nd }}$ or $3^{\text {rd }}$ day of administration, soon after reaching its steady state, to rescue the cycle in a timely manner.

Although proximate, the different values of minimal serum P4 found suggest that the absorption and metabolization in each patient is very variable, warranting monitoring during FET. ${ }^{15,18,28}$ There are few studies evaluating the variation in P4 levels among women on the same dosage and administration interval. The vaginal method directly reaches the uterus (uterine first pass effect), avoiding the hepatic first pass effect and its inherent metabolism, leading to serum levels that are higher and more sustained than the oral route and to higher endometrial levels than the IM or SC routes. ${ }^{28-30}$ Therefore, results obtained for serum values with one specific method of administration should not be extrapolated to another method.

As strengths of the present study, we highlight the fact that most of the data $(n=102)$ was collected prospectively in a single center and in a relatively short period. Moreover, only autologous oocytes were used, with only blastocysts being transferred and with the same route of administration and measurement of P4.

As potential limitations, we must mention the number of cases, which, although suggesting worse outcome in the extremes, was insufficient to safely determine cutoff values that can predict worst results. Moreover, patients with a transfer of either one or two embryos were included, which, despite being of good quality, contributed to the heterogeneity of our sample. Another limitation is the fact that none of the embryos was genetically screened before transfer, which means that, by random effect, aneuploidy embryos could have been more frequent in the $1^{\text {st }}$ quartile and, in fact, be responsible for such a higher miscarriage rate.

\section{Conclusion}

The measurement of serum P4 on the day of transfer of frozen embryos can be important to improve results. Women with lower P4 levels $(<10.7 \mathrm{ng} / \mathrm{mL})$ had more miscarriages. No statistically significant results were identified in women with lower $(<10.7 \mathrm{ng} / \mathrm{mL})$ or higher $(15.7 \mathrm{ng} / \mathrm{mL})$ P4 compared with intermediate ones.

\section{Contributions}

All authors were involved in the design and interpretation of the analyses; they contributed to the writing and read and approved the final manuscript.

\section{Conflict of Interests}

The authors have no conflict of interests to declare.

\section{References}

1 Rienzi L, Gracia C, Maggiulli R, LaBarbera AR, Kaser DJ, Ubaldi FM, et al. Oocyte, embryo and blastocyst cryopreservation in ART: systematic review and meta-analysis comparing slow-freezing versus vitrification to produce evidence for the development of global guidance. Hum Reprod Update. 2017;23(02):139-155. Doi: 10.1093/humupd/dmw038

2 De Geyter C, Calhaz-Jorge C, Kupka MS, Wyns C, Mocanu E, Motrenko T, et al; European IVF-monitoring Consortium (EIM) for the European Society of Human Reproduction and Embryology (ESHRE) ART in Europe, 2014: results generated from European registries by ESHRE: The European IVF-monitoring Consortium (EIM) for the European Society of Human Reproduction and Embryology (ESHRE). Hum Reprod. 2018;33(09):1586-1601. Doi: 10.1093/humrep/dey242

3 Devroey P, Polyzos NP, Blockeel C. An OHSS-Free Clinic by segmentation of IVF treatment. Hum Reprod. 2011;26(10):2593-2597. Doi: 10.1093/humrep/der251

4 Coates A, Kung A, Mounts E, Hesla J, Bankowski B, Barbieri E, et al. Optimal euploid embryo transfer strategy, fresh versus frozen, after preimplantation genetic screening with next generation sequencing: a randomized controlled trial. Fertil Steril. 2017; 107(03):723-730.e3. Doi: 10.1016/j.fertnstert.2016.12.022

5 Groenewoud ER, Cohlen BJ, Macklon NS. Programming the endometrium for deferred transfer of cryopreserved embryos: hormone replacement versus modified natural cycles. Fertil Steril. 2018;109(05):768-774. Doi: 10.1016/j.fertnstert.2018.02.135

6 Yarali H, Polat M, Mumusoglu S, Yarali I, Bozdag G. Preparation of endometrium for frozen embryo replacement cycles: a systematic review and meta-analysis. J Assist Reprod Genet. 2016;33(10): 1287-1304. Doi: 10.1007/s10815-016-0787-0

7 Blesa D, Ruiz-Alonso M, Simón C. Clinical management of endometrial receptivity. Semin Reprod Med. 2014;32(05):410-413. Doi: $10.1055 / \mathrm{s}-0034-1376360$

8 El-Toukhy T, Coomarasamy A, Khairy M, Sunkara K, Seed P, KhalafY, et al. The relationship between endometrial thickness and outcome of medicated frozen embryo replacement cycles. Fertil Steril. 2008; 89(04):832-839. Doi: 10.1016/j.fertnstert.2007.04.031

9 Gellersen B, Brosens JJ. Cyclic decidualization of the human endometrium in reproductive health and failure. Endocr Rev. 2014;35(06):851-905. Doi: 10.1210/er.2014-1045

10 van der Linden M, Buckingham K, Farquhar C, Kremer JA, Metwally M. Luteal phase support for assisted reproduction cycles. Cochrane Database Syst Rev. 2015;(07):CD009154. Doi: 10.1002/14651858.CD009154.pub3

11 Casper RF, Yanushpolsky EH. Optimal endometrial preparation for frozen embryo transfer cycles: window of implantation and progesterone support. Fertil Steril. 2016;105(04):867-872. Doi: 10.1016/j.fertnstert.2016.01.006

12 Griesinger G, Tournaye H, Macklon N, Petraglia F, Arck P, Blockeel $C$, et al. Dydrogesterone: pharmacological profile and mechanism of action as luteal phase support in assisted reproduction. Reprod Biomed Online. 2019;38(02):249-259. Doi: 10.1016/j.rbmo. 2018.11.017

13 Rashidi BH, Ghazizadeh M, Tehrani Nejad ES, Bagheri M, Gorginzadeh M. Oral dydrogesterone for luteal support in frozen-thawed embryo transfer artificial cycles: a pilot randomized controlled trial. Asian Pac J Reprod. 2016;5(06):490-494. Doi: 10.1016/j. apjr.2016.10.002

14 Gaggiotti-Marre S, Martinez F, Coll L, Garcia S, Álvarez M, Parriego $\mathrm{M}$, et al. Low serum progesterone the day prior to frozen embryo transfer of euploid embryos is associated with significant reduction in live birth rates. Gynecol Endocrinol. 2019;35(05): 439-442. Doi: 10.1080/09513590.2018.1534952

15 Labarta E, Mariani G, Holtmann N, Celada P, Remohí J, Bosch E. Low serum progesterone on the day of embryo transfer is associated with a diminished ongoing pregnancy rate in oocyte donation cycles after artificial endometrial preparation: a prospective study. Hum Reprod. 2017;32(12):2437-2442. Doi: 10.1093/humrep/dex316 
16 Kofinas JD, Blakemore J, McCulloh DH, Grifo J. Serum progesterone levels greater than $20 \mathrm{ng} / \mathrm{dl}$ on day of embryo transfer are associated with lower live birth and higher pregnancy loss rates. J Assist Reprod Genet. 2015;32(09):1395-1399. Doi: 10.1007/ s10815-015-0546-7

17 ALPHA Scientists In Reproductive Medicine ESHRE Special Interest Group Embryology. Istanbul consensus workshop on embryo assessment: proceedings of an expert meeting. Reprod Biomed Online. 2011;22(06):632-646. Doi: 10.1016/j.rbmo. 2011.02.001

18 Brady PC, Kaser DJ, Ginsburg ES, Ashby RK, Missmer SA, Correia $\mathrm{KF}$, et al. Serum progesterone concentration on day of embryo transfer in donor oocyte cycles. J Assist Reprod Genet. 2014;31 (05):569-575. Doi: 10.1007/s10815-014-0199-y

19 Yovich JL, Conceicao JL, Stanger JD, Hinchliffe PM, Keane KN. Midluteal serum progesterone concentrations govern implantation rates for cryopreserved embryo transfers conducted under hormone replacement. Reprod Biomed Online. 2015;31(02): 180-191. Doi: 10.1016/j.rbmo.2015.05.005

20 Basnayake SK, Volovsky M, Rombauts L, Osianlis T, Vollenhoven B, Healey M. Progesterone concentrations and dosage with frozen embryo transfers - What's best? Aust N Z J Obstet Gynaecol. 2018; 58(05):533-538. Doi: 10.1111/ajo.12757

21 Alsbjerg B, Thomsen L, Elbaek HO, Laursen R, Povlsen BB, Haahr T, et al. Progesterone levels on pregnancy test day after hormone replacement therapy-cryopreserved embryo transfer cycles and related reproductive outcomes. Reprod Biomed Online. 2018;37 (05):641-647. Doi: 10.1016/j.rbmo.2018.08.022

22 Cédrin-Durnerin I, Isnard T, Mahdjoub S, Sonigo C, Seroka A, Comtet $\mathrm{M}$, et al. Serum progesterone concentration and live birth rate in frozen-thawed embryo transfers with hormonally prepared endometrium. Reprod Biomed Online. 2019;38(03): 472-480. Doi: 10.1016/j.rbmo.2018.11.026
23 Labarta ED, Mariani G, Paolelli S, et al. O-173: A large prospective trial in unselected population confirms that low serum progesterone on the day of embryo transfer impairs pregnancy outcome in artificial cycles. Hum Reprod 2019;34 Suppl 1:82. Abstract Book - ESHRE 2019-Vienna, Austria, 2019 Jun 23-26.

24 Hull MG, Savage PE, Bromham DR, Ismail AA, Morris AF. The value of a single serum progesterone measurement in the midluteal phase as a criterion of a potentially fertile cycle ("ovulation") derived form treated and untreated conception cycles. Fertil Steril. 1982;37(03): 355-360. Doi: 10.1016/s0015-0282(16)46095-4

25 Jordan J, Craig K, Clifton DK, Soules MR. Luteal phase defect: the sensitivity and specificity of diagnostic methods in common clinical use. Fertil Steril. 1994;62(01):54-62. Doi: 10.1016/ s0015-0282(16)56815-0

26 Murray MJ, Meyer WR, Zaino RJ, Lessey BA, Novotny DB, Ireland K, et al. A critical analysis of the accuracy, reproducibility, and clinical utility of histologic endometrial dating in fertile women. Fertil Steril. 2004;81 (05):1333-1343. Doi: 10.1016/j.fertnstert.2003.11.030

27 Lessey BA. Assessment of endometrial receptivity. Fertil Steril. 2011;96(03):522-529. Doi: 10.1016/j.fertnstert.2011.07.1095

28 Nahoul K, Dehennin L, Jondet M, Roger M. Profiles of plasma estrogens, progesterone and their metabolites after oral or vaginal administration of estradiol or progesterone. Maturitas. 1993; 16(03):185-202. Doi: 10.1016/0378-5122(93)90064-o

29 Miles RA, Paulson RJ, Lobo RA, Press MF, Dahmoush L, Sauer MV. Pharmacokinetics and endometrial tissue levels of progesterone after administration by intramuscular and vaginal routes: a comparative study. Fertil Steril. 1994;62(03):485-490. Doi: 10.1016/s0015-0282(16)56935-0

30 Paulson RJ, Collins MG, Yankov VI. Progesterone pharmacokinetics and pharmacodynamics with 3 dosages and 2 regimens of an effervescent micronized progesterone vaginal insert. J Clin Endocrinol Metab. 2014;99(11):4241-4249. Doi: 10.1210/jc.2013-3937 